\title{
A comprehensive evaluation of the crustacean assemblages in southern Iberian Mediterranean wetlands
}

\author{
Juan Diego GILBERT, ${ }^{1}$ Inmaculada DE VICENTE, ${ }^{2}$ Fernando ORTEGA, ${ }^{1}$ Raquel JIMÉNEZ-MELERO,, 3 \\ Gema PARRA, ${ }^{1,3}$ Francisco GUERRERO ${ }^{1,3^{*}}$ \\ ${ }^{1}$ Department of Animal Biology, Plant Biology and Ecology, University of Jaén, Campus de Las Lagunillas, s/n, 23071 Jaén; \\ ${ }^{2}$ Department of Ecology, University of Granada, Campus de Fuentenueva, s/n, 18071 Granada; ${ }^{3}$ Center for Advanced Studies in Earth \\ Sciences, University of Jaén, Campus de Las Lagunillas, s/n, 23071 Jaén, Spain \\ *Corresponding author: fguerre@ujaen.es
}

\begin{abstract}
Although Mediterranean wetlands were recognized as biodiversity hotspots, most of them are nowadays threatened by human activities that have led to habitat loss and degradation. A total of 36 wetlands were monitored to assess species richness of branchiopods and copepods by using accumulation curves and non-parametric estimators. Three different types of wetlands were identified: i) temporary freshwaters-subsaline-hyposaline (TFSH); ii) permanent freshwaters-subsaline-hyposaline (PFSH); and iii) mesosaline-hypersaline (MH) wetlands (including temporary and permanent ones). A total of 60 species were recorded; they belong to seven different orders. A large number (37\%) of rare species (present in only one wetland) were found while only 11\% of the total species were common (i.e., present in more than $20 \%$ of wetlands). Species richness was related to wetland typology, with the largest number of species observed in TFSH, followed by MH and by PFSH wetlands. We have found that rare species are mainly present in temporary wetlands, the most vulnerable to hydrological changes; hence, these types of wetlands represent unique sites deserving conservation.
\end{abstract}

Key words: Biodiversity, conservation, Mediterranean wetlands, non-parametric estimators, zooplankton.

Received: April 2014. Accepted: August 2014.

\section{INTRODUCTION}

The Mediterranean region is considered as one of the most important biodiversity hotspots in the world (Myers et al., 2000). In particular, the southern Iberian Peninsula is an area of special interest as it is located in one of the most arid zones of Europe and comprises a wide range of aquatic ecosystems, from freshwater to hypersaline ones (Sánchez-Fernández et al., 2004), which represent an important component of the landscape.

Mediterranean wetlands are characterized by social, economic, cultural, scientific and environmental values (see Williams, 1999 among others). These ecosystems have been considered as unique because of their ecological characteristics, which frequently hold exclusive communities of aquatic organisms, and play an important role in the maintenance of regional biodiversity (Williams, 1999; De Meester et al., 2005; Oertli et al., 2005; Céréghino et al., 2008). However, this value has been frequently overlooked, contributing to their neglect and inadequate management (Semlitsch and Bodie, 2005). In fact, nowadays, Mediterranean wetlands are highly endangered, suffering widespread degradation and loss due to increase of intensive cultivation, livestock, and urban uses (Beja and Alcazar, 2003; García-Muñoz et al., 2010).

Zooplankton is one of the most important communities present in these wetlands. Zooplanktonic assemblages have previously been used for the ecological evaluation of wetlands (Gannon and Stemberger, 1978; Caramujo and Boavida, 2000; Bianchi et al., 2003; Boix et al., 2005; Parra et al., 2009). However, recently the European Water Framework Directive (WFD) has excluded this community from the evaluation criteria in the protection of wetlands. Some authors have considered this exclusion as an error (Jeppesen et al., 2011 and references therein), because the knowledge of zooplankton diversity is a necessary tool for the development of strategies for the management and protection of aquatic biodiversity at landscape level (Marrone et al., 2006; De Bie et al., 2008). Moreover, the lack of fish community in temporary wetlands, denote the importance to include zooplankton in the evaluation of ecological quality and conservation procedures in Mediterranean wetlands.

Previous studies focusing on zooplankton richness in the Mediterranean area are scarce in comparison to other climatic regions (Álvarez-Cobelas et al., 2005). The aim of this study has been the development of monitoring methods to evaluate zooplankton biodiversity (using as target groups copepods and branchiopods) in a Mediterranean area in southern Spain in order to build models for the entire Mediterranean region. 


\section{METHODS}

\section{Study wetlands}

In the present study, we selected a total of 36 endorheic wetlands (Fig. 1) widely differing in their limnological characteristics (Tab. 1). The term endorheic reflects the closed nature (no outlet) of the drainage systems of wetlands (Dantín, 1929; 1940; Allan et al., 1995). In particular the studied wetlands differ in altitude (265 to $1582 \mathrm{~m}$ asl) and in morphological characteristics: maximum area ranging from 0.2 to 46 ha and maximum depth from 10 to $456 \mathrm{~cm}$ (Ortega et al., 2003, 2006). All these wetlands are located in the Alto Guadalquivir, a representative region of the southern Iberian Peninsula (Spain), with a Mediterranean continental climate, a Mediterranean type of climate with continental tendencies (Capel Molina, 1981; Díaz de la Guardia et al., 2003). The three main morphologic and geologic units that exist in Andalusia are present in the study area: Sierra Morena siliceous mountains at the north, the Guadalquivir depression with olitostromics deposits and Triassic rocks in the centre and Baetic calcareous mountains in the south and east (Vera, 1994). The valley of the Guadalquivir River represents the most important geographical entity of this district, being a large proportion of this area which is characterized by a semiarid climate with a mean annual precipitation around $400 \mathrm{~mm}$, although aridity decreases from the Guadalquivir valley to mountain areas located in the north, south and east of this valley (AEMET, 2011).

\section{Sampling}

Accordingly to the high inter-annual variability that characterized Mediterranean wetlands, zooplankton samples (branchiopods and copepods) were collected seasonally during a multi-year sampling (1998-2002 and 2010 , representing a great range of weather conditions that affect Mediterranean wetlands) to obtain cumulative zooplankton species richness (presence-absence data). In all cases, samples (integrated composite samples) were collected along two longitudinal transects, one from the

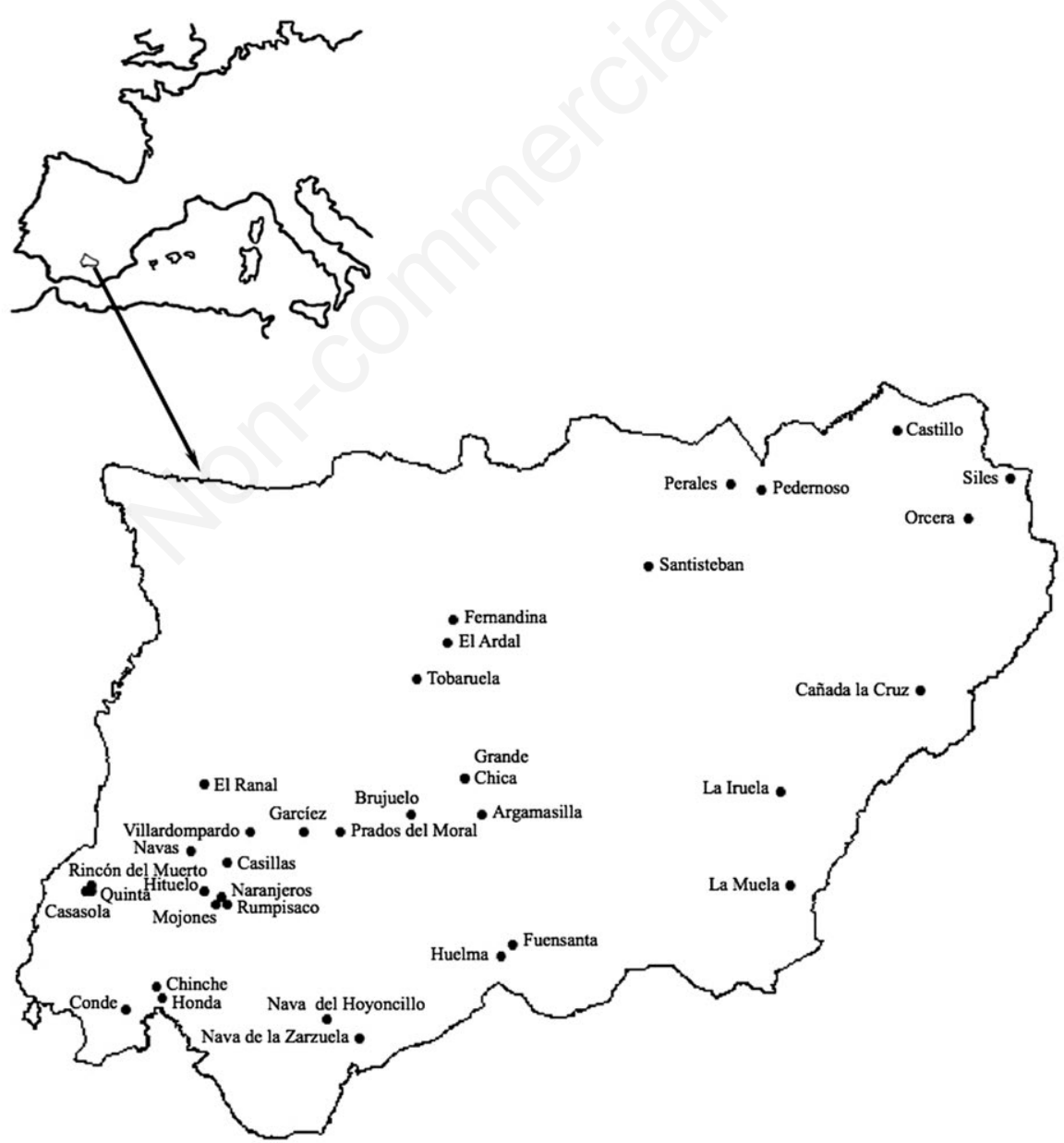

Fig. 1. Localization of the Alto Guadalquivir region (south of Spain) and wetlands included in the study. 
shore line to the open water, and the other along the shore line. Sampling strategy allowed us to evaluate the crustacean assemblages considering the spatial and temporal heterogeneity characterizing the studied wetlands. Samples were collected through $63-\mu \mathrm{m}$ mesh size plankton net and preserved in situ with $4 \%$ formalin (f.c.). Once in the laboratory, all organisms were identified to species level, according to Dussart (1967, 1969), Dussart and Defaye (1995), Einsle (1996), and Ranga-Reddy (1994) for copepods and Alonso (1996) for branchiopods.

\section{Data analysis}

Previous to analysis, wetlands were grouped based on the criteria obtained by Boix et al. (2005) for Mediterranean wetlands, according to conductivity and temporality values. In our case, the scarce number of saline wetlands in the study area (salinity threshold $>5 \mathrm{~g}$ $\mathrm{L}^{-1}$ ) prevented us from producing two categories in relation to temporality. Hence, three different categories of wetlands were identified: i) temporary freshwatersubsaline-hyposaline wetlands (TFSH); ii) permanent freshwater-subsaline-hyposaline wetlands (PFSH); and iii) mesosaline-hypersaline wetlands $(\mathrm{MH})$.

In order to describe diversity patterns among different wetland groups, parameters such as singularity and species richness were estimated. For all parameters, presence-absence data of total zooplankton species (sum of branchiopods and copepods), total branchiopods and total copepods were considered. First, in order to identify those wetlands characterized by a greater number of unique species, a singularity index including the complete dataset, was applied (Boix et al., 2008):

Tab. 1. Characteristics of the studied wetlands, ordered by increasing salinity from freshwater to hypersaline ones. Data obtained from this study and Ortega et al. $(2003,2006)$.

\begin{tabular}{|c|c|c|c|c|c|}
\hline & $\begin{array}{l}\text { Coordinates } \\
\text { (UTM) }\end{array}$ & $\begin{array}{l}\text { Altitude } \\
\text { (m) }\end{array}$ & $\begin{array}{l}\text { Maximum area } \\
\text { (ha) }\end{array}$ & $\begin{array}{l}\text { Maximum depth } \\
(\mathrm{cm})\end{array}$ & $\begin{array}{l}\text { Salinity } \\
\left(\mathrm{g} \mathrm{L}^{-1}\right)\end{array}$ \\
\hline Casasola & 30SUG8780 & 285 & 3.60 & 75 & 0.35 \\
\hline Perales & 30SVH9548 & 757 & 5.20 & 105 & 0.38 \\
\hline Pedernoso & 30SWH0047 & 724 & 1.40 & 110 & 0.45 \\
\hline Mojones & 30SVG0877 & 493 & 4.50 & 122 & 0.51 \\
\hline Orcera & 30SWH3542 & 1270 & 0.50 & 172 & 0.51 \\
\hline Santisteban & 30SVH8134 & 637 & 3.00 & 90 & 0.51 \\
\hline Hituelo & 30SVG0679 & 476 & 3.80 & 179 & 0.54 \\
\hline Fuensanta & 30SVG5870 & 1000 & 1.30 & 22 & 0.56 \\
\hline Rumpisaco & 30SVG1077 & 538 & 4.00 & 33 & 0.56 \\
\hline Siles & 30SWH4249 & 1280 & 1.30 & 234 & 0.59 \\
\hline Nava de la Zarzuela & 30SVG3219 & 1254 & 0.20 & 30 & 0.59 \\
\hline Nava del Hoyoncillo & 30SVG2767 & 1465 & 0.28 & 30 & 0.59 \\
\hline Navas & 30SVG0486 & 378 & 3.50 & 223 & 0.68 \\
\hline Naranjeros* & 30SVG0978 & 508 & 5.20 & 456 & 0.76 \\
\hline Fernandina & 30SVH4805 & 482 & 0.21 & 15 & 0.84 \\
\hline Grande* & 30SVG5098 & 368 & 22.90 & 350 & 1.00 \\
\hline Ardal & 30 SVH4721 & 400 & 0.50 & 28 & 1.14 \\
\hline Tobaruela & $30 \mathrm{SVH} 4215$ & 363 & 1.70 & 70 & 1.21 \\
\hline Cañada la Cruz & 30 SWH2713 & 1582 & 3.10 & 32 & 1.25 \\
\hline Chica & 30SVG5098 & 370 & 5.80 & 80 & 1.25 \\
\hline Castillo & 30SWH2357 & 780 & 0.60 & 147 & 1.33 \\
\hline Ranal & 30SVG0697 & 340 & 10.70 & 81 & 1.42 \\
\hline Argamasilla & 30SVG5392 & 484 & 4.80 & 220 & 1.50 \\
\hline Iruela & 30SWG0322 & 1515 & 0.15 & 28 & 1.50 \\
\hline Villardompardo & 30SVG1489 & 360 & 1.70 & 318 & 1.58 \\
\hline Huelma & 30SVG5668 & 1224 & 2.00 & 10 & 1.66 \\
\hline Muela & 30SWH0610 & 1324 & 5.40 & 35 & 1.76 \\
\hline Casillas & 30SVG1084 & 442 & 2.70 & 241 & 2.15 \\
\hline Garcíez* & 30SVG2389 & 441 & 7.90 & 355 & 3.10 \\
\hline Prados del Moral & 30SVG2989 & 389 & 4.80 & 120 & 3.50 \\
\hline Chinche & 30SUG9863 & 452 & 4.70 & 107 & 4.50 \\
\hline Conde & 30SUG9359 & 412 & 46.00 & 120 & 24.82 \\
\hline Quinta & 30SUG8679 & 289 & 7.70 & 199 & 24.82 \\
\hline Brujuelo & 30SVG4191 & 458 & 4.20 & 212 & 33.19 \\
\hline Rincón del Muerto & 30SUG8779 & 265 & 4.20 & 166 & 82.29 \\
\hline Honda* & 30SUG9961 & 446 & 9.90 & 316 & 86.56 \\
\hline
\end{tabular}

*Permanent wetland. 
$S=(e / E) \cdot 100$

(eq. 1)

where $S$ is the index of singularity for one wetland typology, $e$ is the number of species found in one wetland typology and not found in other typology, and $E$ is the total number of species found in this wetland typology.

In relation to the species richness, it is important to recognize the inherent difficulty for recording all species in a fauna inventory, especially for the case of invertebrates (Jiménez-Valverde and Hortal, 2003; Hortal et al., 2006). As a result, different methods were proposed in the literature for estimating the number of species in a given area (González-Oreja et al., 2010). In this study, two approaches were used to provide valid comparisons among the inventories of species of the different wetland groups, and so to evaluate the completeness of crustacean species inventories. Estimations were performed by randomised resampling with replacement from a pooled group of samples; this implies that each species can appear in any pooled sample. Walther and Moore (2005) suggested that the generated data are independent of one another. Samples-based curves were obtained using EstimateS 8.2.0 software. The first approach was based on species accumulation curves, in which cumulative species richness is plotted against the number of samples (Moreno and Halffter, 2000). Species accumulation curves were obtained by using EstimateS 8.2.0 software. Subsequently, Clench equation $(S n)$ was assigned to describe the species accumulation model, allowing us to obtain an ideal function that describes the species accumulation with the increase of sampling effort (Soberon and Llorente, 1993; Moreno and Halffter, 2000; Hortal et al., 2006):

$$
S_{n}=a \cdot n /(1+b \cdot n)
$$

where $a$ is the rate of increase of new species at the beginning of the inventory, $b$ is a parameter related to the shape of the curve, and $n$ is the sample effort. Data were adjusted by using non-linear estimation of Hooke-Jeeves, using Statistica 7.0 software. This fitting is based on geometric procedures to minimize the loss function (see Jiménez-Valverde and Hortal, 2003; StatSoft, 2004). The parameters of the Clench equation gave us information about: i) the reliability of our inventories $(R i)$; ii) the rate of recorded fauna $(R f)$; iii) the sampling effort needed to identify all species $(n q)$; and iv) the total number of theoretical species present in each wetland type (Nts):

$R_{i}=a /(1+b \cdot n)^{2}$

$R_{f}=S_{\text {obs }} /(a / b)$

$\mathrm{S}_{\mathrm{obs}}$ : observed species richness

$n_{q}=q /[b \cdot(1-q)]$

q: percentage of recorded species (in our case $90 \%$ )
$N_{t s}=a / b$

In our study we have considered that $R i$ values lower than 0.1 indicated that our inventories were near to be complete (Hortal and Lobo, 2002). In other studies, the inventories were considered as representative when $70 \%$ of estimated identified species were collected (Hortal and Lobo, 2002).

In the second approach, rarefaction curves (Longino et al., 2002) were used to obtain an estimation of total zooplankton richness for each wetland group. In particular, the observed richness (Sobs - Mao Tau), and two nonparametric estimators, based on presence-absence data sets, were calculated: i) ICE (Incidence-based Coverage Estimator); and ii) corrected version of Chao2 (Incidencebased estimator). The corrected Chao 2 version was used because some problems were detected when the infrequent species were unique (Colwell, 2005). Both estimators were calculated with 100 randomizations (Colwell, 2005; Hortal et al., 2006) and by using the software EstimateS 8.2.0. Finally, in order to quantify the performance of the above mentioned non-parametric estimators, we have calculated bias, precision and accuracy for Sobs (Mao Tau), ICE and corrected Chao2 [see Walther and Moore (2005) for more detailed information]. In brief, bias (PAR) reflects underor overestimates of the true value of species richness. Precision (CV) is measured as the coefficient of variation, without considering if the estimator is biased or not. Accuracy (SRMSE) takes into account the difference between the estimated and the total species. The ideal characteristics for a good estimator are bias values close to zero and small precision values (Walther and Martin, 2001).

$P A R=\frac{1}{n} \sum_{j=1}^{n}\left(100 E_{j} / A\right)$

$$
C V=\frac{100 S D}{\bar{E}}
$$

SRMSE $=\frac{1}{A} \sqrt{\frac{1}{n} \sum_{j=1}^{n}\left(E_{j}-A\right)^{2}}$

where $A$ is the asymptotic or total species richness (calculated following Colwell, 2005); $E_{j}$ is the estimated species richness for the $j_{t h}$ sample; and $n$ is the number of samples.

\section{RESULTS}

\section{Crustacean composition}

A total of 60 species (branchiopods and copepods) were recorded in the Alto Guadalquivir region, belonging to seven orders (Tab. 2). Twenty-two of the recorded species were copepods (7 Calanoida, 12 Cyclopoida and 3 Harpacticoida), and 38 were branchiopods (4 Anostraca, 1 Ctenopoda, 32 Anomopoda and 1 Notostraca). A large number $(37 \%)$ of rare species (present in only one wetland) were found (15 branchiopods and 7 copepods 


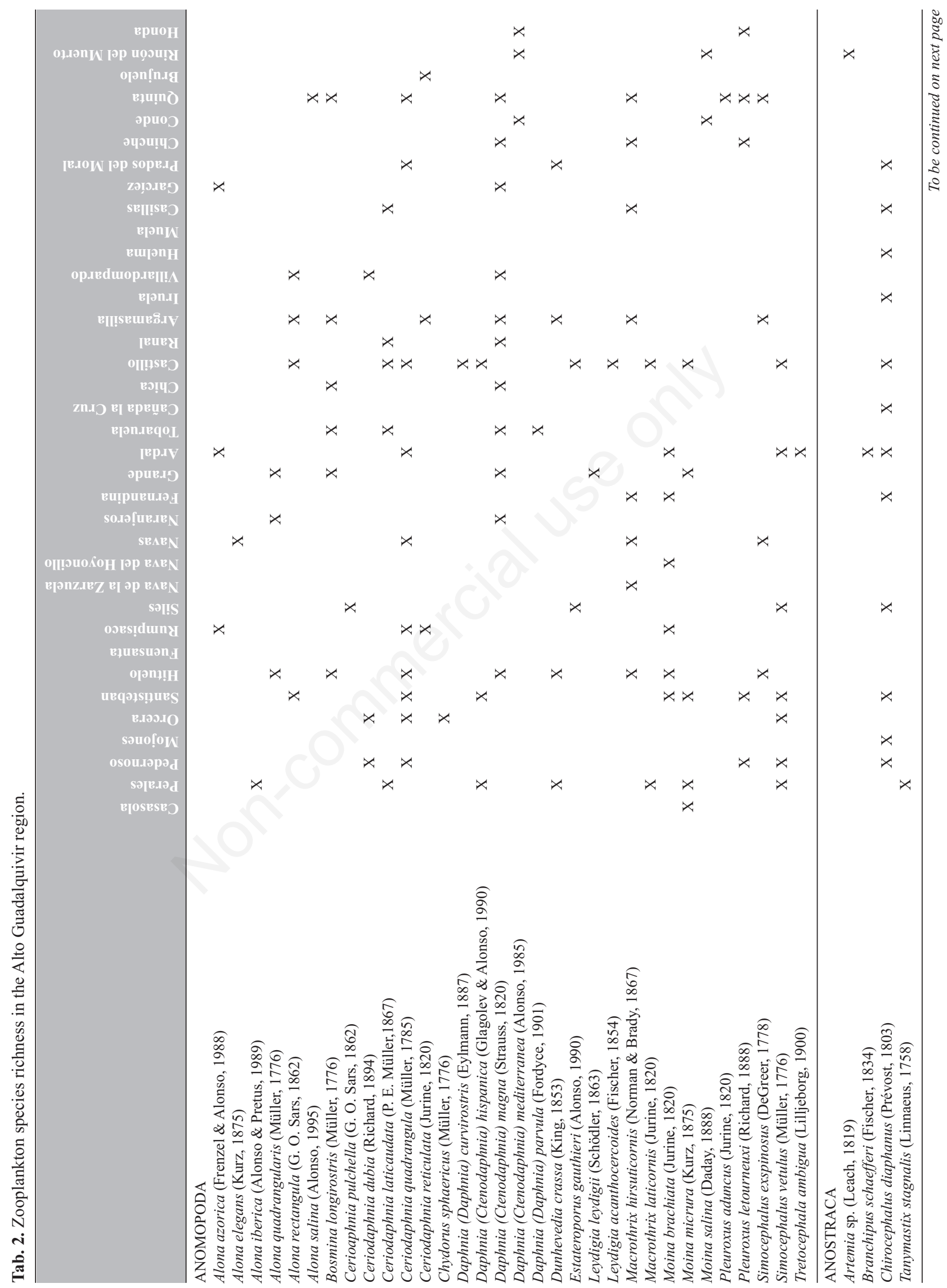




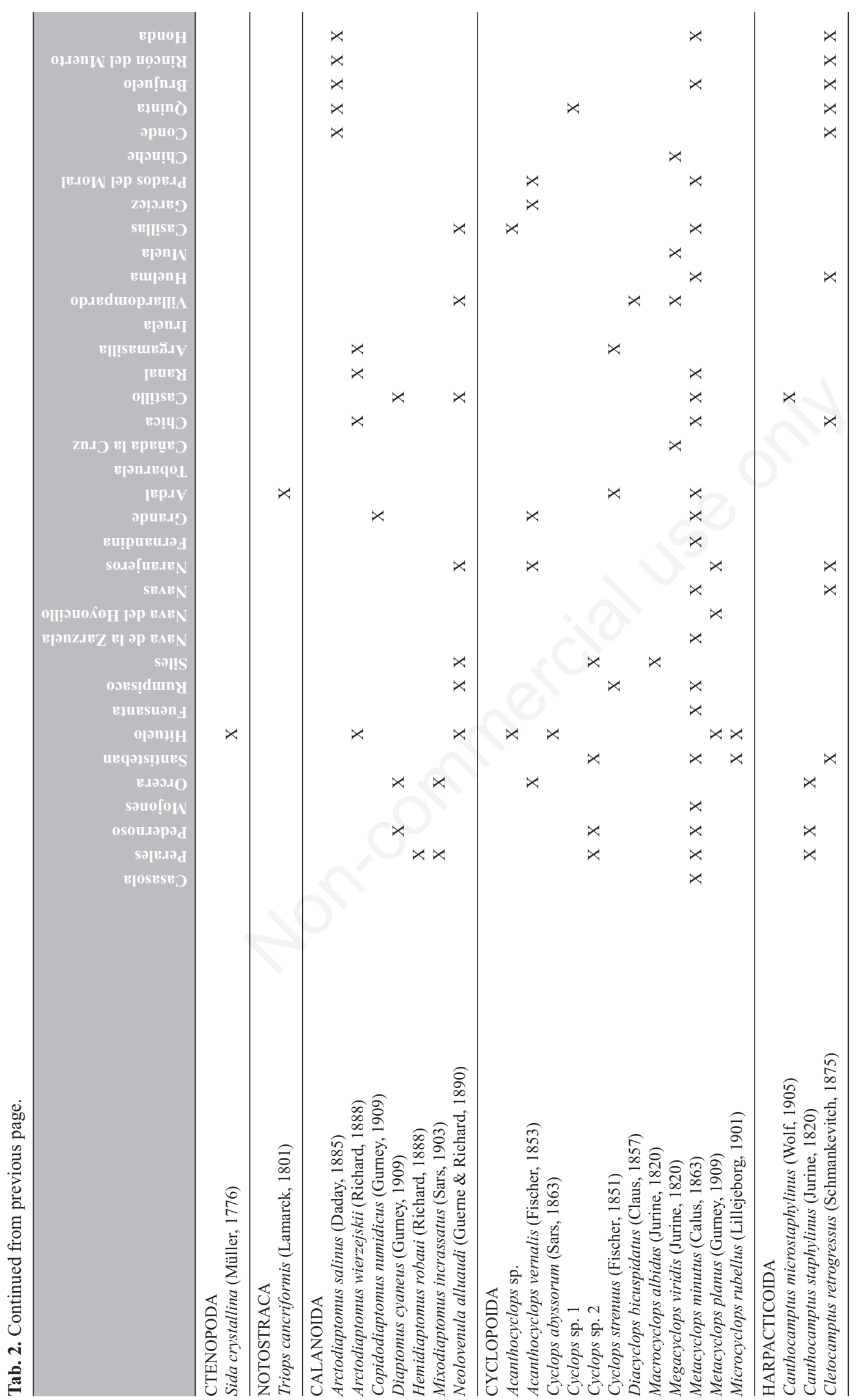


species; Tab. 2), while only $11 \%$ of the total species number ( 4 branchiopods and 3 copepods species) were common (present in more than $20 \%$ of the wetlands).

\section{Biodiversity}

Species richness differed between the three wetland typologies previously mentioned, with the largest number of species recorded in TFSH (51 species; $4 \pm 2$ species per sample), followed by MH (16 species; $3 \pm 1$ species per sample) and PFSH (12 species; $3 \pm 1$ species per sample). Fig. 2 shows that the highest values of singularity for branchiopods, copepods and total zooplankton species were also found in TFSH wetlands. The accumulation curves obtained by using Clench equation in the different wetland types (Tab. 3), have reflected that inventories were near to be completed and could be considered as representative, with values of reliability below 0.1 . The rate of recorded fauna was around $85 \%$ evidencing that sampling strategy was effective, except for the case of branchiopods in $\mathrm{MH}$ wetlands, with a $73 \%$ rate of recorded fauna. In general, results for the three wetland types have shown that the species accumulation curves obtained by using both, observed richness (Mao-Tau) and non-parametric estimators (ICE and Chao-2) were close to reaching the asymptote (Fig. 3). This result again confirms that a significant proportion of species richness has been effectively surveyed, and they also agree with the values of reliability, close to 0.1 (Tab. 3).
Finally, in relation to the quality of the non-parametric estimators, ICE was the best estimator for predicting species richness as it was reflected by values which were less biased, more precise and accurate (Tab. 4).

\section{DISCUSSION}

This study has revealed that Alto Guadalquivir wetlands are generally characterized by rich crustacean

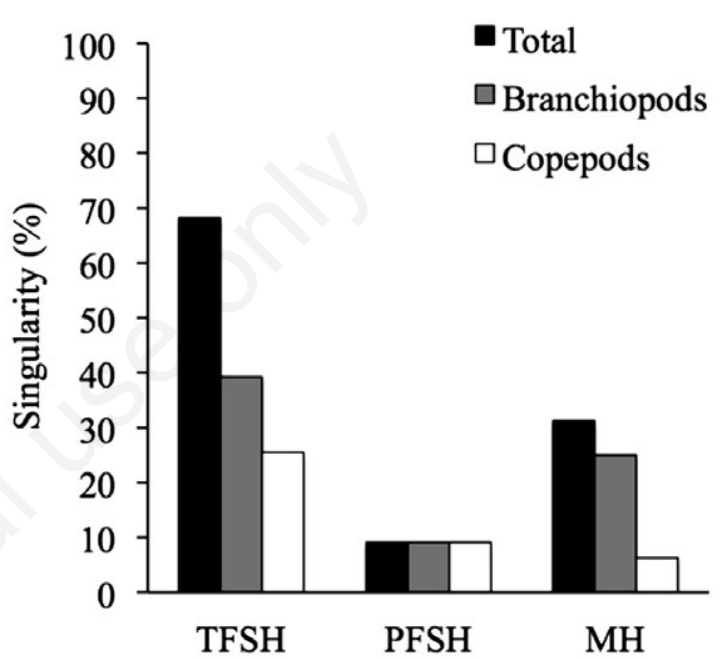

Fig. 2. Values of singularity obtained for each wetland type.

Tab. 3. Results of species accumulation curves (Clench equation) for the different wetland types.

\begin{tabular}{|c|c|c|c|}
\hline & Total & Branchiopods & Copepods \\
\hline $\begin{array}{l}\text { TFSH } \\
\text { Cumulative species richness } \\
\text { R2 Clench model } \\
\text { Reliability of inventory } \\
\text { Rate of registered fauna (\%) } \\
\text { Sampling effort necessary to determine } 90 \% \text { of species } \\
\text { Total number of theoretical species }\end{array}$ & $\begin{array}{c}51 \\
0.9997 \\
0.0794 \\
85.51 \\
135 \\
54\end{array}$ & $\begin{array}{c}32 \\
0.9998 \\
0.0507 \\
84.88 \\
140 \\
34\end{array}$ & $\begin{array}{c}19 \\
0.9992 \\
0.0285 \\
86.61 \\
126 \\
20\end{array}$ \\
\hline $\begin{array}{l}\text { PFSH } \\
\text { Cumulative species richness } \\
\text { R2 Clench model } \\
\text { Reliability of inventory } \\
\text { Rate of registered fauna (\%) } \\
\text { Sampling effort necessary to determine } 90 \% \text { of species } \\
\text { Total number of theoretical species }\end{array}$ & $\begin{array}{c}12 \\
0.9973 \\
0.0926 \\
83.42 \\
38 \\
13\end{array}$ & $\begin{array}{c}6 \\
0.9992 \\
0.0451 \\
83.61 \\
36 \\
7\end{array}$ & $\begin{array}{c}6 \\
0.9917 \\
0.0478 \\
83.02 \\
41 \\
6\end{array}$ \\
\hline $\begin{array}{l}\text { MH } \\
\text { Cumulative species richness } \\
\text { R2 Clench model } \\
\text { Reliability of inventory } \\
\text { Rate of registered fauna (\%) } \\
\text { Sampling effort necessary to determine } 90 \% \text { of species } \\
\text { Total number of theoretical species }\end{array}$ & $\begin{array}{c}16 \\
0.9990 \\
0.0657 \\
86.38 \\
59 \\
16\end{array}$ & $\begin{array}{c}12 \\
0.9990 \\
0.0831 \\
72.56 \\
120 \\
13\end{array}$ & $\begin{array}{c}4 \\
0.995 \\
0.0040 \\
97.56 \\
11 \\
4\end{array}$ \\
\hline
\end{tabular}

TFSH, temporary freshwaters-subsaline-hyposaline wetlands; PFSH, permanent freshwaters-subsaline-hyposaline wetlands; MH, mesosaline-hypersaline wetlands. 
assemblages, similarly to other areas of the Iberian Peninsula (Boronat et al., 2001; Frisch et al., 2006; Fahd et al., 2009; Gascón et al., 2009; Caramujo and Boavida, 2010), and to other Mediterranean wetlands (Ripley and Simovich, 2009; Alfonso and Belmonte, 2011). There are several reasons for explaining why the study area is an excellent site for analysing the coupling between zooplankton species richness and composition, with some forcing environmental factors. First, the high zooplankton species richness of the study site, with the presence of several species with special relevance to the Spanish and Andalusia context such as, Copidodiaptomus numidicus, a typical species of the North African, Sardinia and southern Italy fauna, and Neolovenula alluaudi, a species of tropical and Ethiopic origin (Miracle, 1982; Alfonso and Belmonte, 2013); and some species endemic to the Iberian Peninsula such as Alona iberica, Alona salina, and Daphnia hispanica (Alonso, 1996). Second, the existence, in this area, of a wide variety of wetland types in a broad range of ecological gradients (especially in terms of temporality and salinity, see Ortega et al., 2003; Guerrero et al., 2006; Gilbert et al., 2014).

Salinity and hydroperiod are the two main drivers taken into account when classifying Mediterranean wetlands (Boix et al., 2005). Previous studies have observed that salinity and temporality are key factors for determining crustacean species richness and composition in Mediterranean wetlands (Alonso, 1998; Marrone et al., 2006; Brucet et al., 2009). In relation to salinity, we have found typical species of FSH wetlands in terms of occurrence (i.e. Chirocephalus diaphanus and Moina branchiata), and others that appears only in $\mathrm{MH}$ ones (i.e., Arctodiaptomus salinus, Daphnia mediterranea and Moina salina; Tab. 2). However, certain species such as
Cletocamptus retrogressus or Metacyclops minutus, with wide ranges of salinity (Alonso, 1998; Boronat et al., 2001), have masked this pattern, because these species appear in a broad range of wetlands.

Concerning hydroperiod, the scarcity of studied permanent wetlands, an inherent difficulty of the Mediterranean climate (Guerrero, 2009) reduces the probability of finding typical species. Moreover, most of the species found in permanent wetlands were also present in temporary ones. Nevertheless we have detected some differences in the occurrence of zooplankton species between TFSH (i.e., Moina brachiata, C. diaphanus, Cyclops sp. 2 and Simocephalus vetulus) and PFSH (i.e., C. numidicus and Leydigia leidigii). In saline waters, the lack of a clear distinction as a function of hydrology contrasts with other climatic regions for which there is substantial evidence indicating differences in faunal composition related to hydrology, hence reinforcing the idea of the different structure and functioning of Mediterranean wetlands (Eitam et al., 2004; ÁlvarezCobelas et al., 2005).

Our results also suggest that increasing overall salinity has a negative effect on total species richness, since $85 \%$ of the species occur in FSH $v s 26 \%$ in MH. In fact, it is well-known that high salinity values increases biota stress, reducing growth and reproduction rates (Sarma et al., 2006) and leaving the community with only salinitytolerant species adapted to these particular habitat types (Por, 1980). In relation to composition, the total ratio copepod: total zooplankton species richness was lower in saline than in freshwater wetlands, probably due to the dependency of copepods on less fluctuating environmental conditions (Brucet et al., 2005, 2006). By contrast, the total ratio branchiopods: total zooplankton

Tab. 4. Performance of non-parametric estimators for the Alto Guadalquivir data set.

\begin{tabular}{|c|c|c|c|c|c|c|c|c|c|}
\hline & \multicolumn{3}{|c|}{ Total } & \multicolumn{3}{|c|}{ Branchiopods } & \multicolumn{3}{|c|}{ Copepods } \\
\hline & Mao-Tau & ICE & Chao2 & Mao-Tau & $\mathrm{ICE}$ & Chao2 & Mao-Tau & $\mathrm{ICE}$ & Chao2 \\
\hline \multicolumn{10}{|l|}{ TFSH } \\
\hline Predicted species richness & 48 & 50 & 50 & 30 & 31 & 30 & 18 & 20 & 19 \\
\hline Bias & 68.62 & 85.04 & 85.04 & 67.67 & 82.01 & 75.41 & 70.23 & 89.73 & 83.57 \\
\hline Precision & 27.53 & 11.69 & 11.69 & 27.75 & 15.10 & 17.65 & 27.16 & 14.59 & 20.39 \\
\hline Accuracy & 0.37 & 0.18 & 0.18 & 0.37 & 0.22 & 0.28 & 0.35 & 0.17 & 0.24 \\
\hline \multicolumn{10}{|l|}{ PFSH } \\
\hline Predicted species richness & 11 & 13 & 12 & 6 & 6 & 6 & 5 & 7 & 6 \\
\hline Bias & 70.56 & 99.41 & 81.67 & 68.42 & 87.08 & 71.27 & 72.91 & 110.96 & 82.59 \\
\hline Precision & 24.73 & 18.67 & 23.98 & 25.85 & 21.78 & 23.77 & 23.51 & 21.98 & 25.57 \\
\hline Accuracy & 0.34 & 0.18 & 0.26 & 0.36 & 0.23 & 0.33 & 0.32 & 0.26 & 0.27 \\
\hline \multicolumn{10}{|l|}{$\overline{\mathrm{MH}}$} \\
\hline Predicted species richness & 16 & 16 & 15 & 12 & 13 & 12 & 4 & 4 & 4 \\
\hline Bias & 70.42 & 83.26 & 71.56 & 58.51 & 74.22 & 58.72 & 87.95 & 93.17 & 84.96 \\
\hline Precision & 26.08 & 17.05 & 22.29 & 31.65 & 26.85 & 29.10 & 13.30 & 10.28 & 10.99 \\
\hline Accuracy & 0.22 & 0.22 & 0.32 & 0.45 & 0.32 & 0.45 & 0.17 & 0.12 & 0.18 \\
\hline
\end{tabular}

TFSH, temporary freshwaters-subsaline-hyposaline wetlands; PFSH, permanent freshwaters-subsaline-hyposaline wetlands; MH, mesosaline-hypersaline wetlands. 
species richness was greater in saline wetlands, reflecting the higher salinity tolerance of those species in Mediterranean region (Brucet et al., 2009).

The natural fluctuations characterizing Mediterranean wetlands imply a restriction on the assessment of the species richness in a short-temporal scale. Therefore, the cumulative richness in a long time-period provides a larger sample size and so offers a better knowledge of the species richness composition (Fahd et al., 2009). Moreover, the application of these models is recommended when comparing species diversity from sites that differ in their characteristics (Moreno and Halffter, 2000), and the probability of finding new species is improved by increasing the sampling effort (Soberón and Llorente, 1993). Our results for nine species accumulation curves (considering a six-year sampling period), fitted to Clench model, have shown values of recorded fauna of approximately $85 \%$, except in the case of branchiopods richness in saline waters, hence confirming that zooplankton species diversity in the study area has been properly estimated. The cumulative species richness in relation to the total number of theoretical species has differed slightly, except for branchiopods in saline wetlands. Furthermore, the sampling effort necessary to achieve this percentage is arduous, representing a higher effort-cost relationship. Our results suggest that, similar to previous studies (Vandekerkhove et al., 2005), the sampling effort must be more intense in temporary environments with high temporal dynamics and species turnover rates. By contrast, efficient sampling effort is likely to be lower in permanent environments where species replacement occurs slowly. In addition, Shurin et al. (2007) noted that the determination of species richness estimated in short time periods was a good indicator of the biodiversity. In our case, the typical characteristics of Mediterranean wetlands, where the species replacement occurs more quickly, justifies the need for longer time-scale sampling (Fahd et al., 2009). Despite the advantages offered by the accumulation curves to determine the number of species, several studies have demonstrated the suitability of rarefaction curves for reinforcing these results (Hortal et al., 2006). Three aspects must be taken into account when applying this methodology (Walther and Martin, 2001). Firstly, an error measure associated to an estimator is not very useful. Secondly, it is necessary to establish an appropriate sampling unit, and thirdly, the performance of the estimators depends on the quality of the data. As a result, and considering that our sampling effort was relatively low (six-years but only seasonal sampling), the use of two non-parametric estimators (ICE and Chao2) which are unbiased and precisely accurate (Hortal et al., 2006) justified this approach in fluctuating environments. However, in all cases the most appropriate estimator
(ICE) tended to underestimate the species richness, except for the case of copepods in PFSH wetlands.

Species richness and singularity were much higher in temporal than in permanent freshwater wetlands. Similar results, related to species richness, were documented in other Mediterranean wetlands (Frisch et al., 2006; Boix et al., 2008). One likely explanation is the well-known intermediate-disturbance hypothesis (Connell, 1978) where recurrent disturbances (alternation of flood and droughts) favour the removal of dominant species making the resources available to a larger number of species (Denslow, 1985). That is, the number of species that can coexist increases directly with increasing environmental variance. In this replacement dynamic, the existence of an egg bank (De Stasio, 1989; Vandekerkhove et al., 2005; Angeler, 2007; Esteban and Finlay, 2010; Galotti et $a l ., 2014)$ could play an important role in the presence of one or another species. The zooplankton dormant stages are considered one of the most important elements in the colonisation process during early temporary pond succession (Angeler et al., 2008). So these cryptic stages are an essential part of the zooplankton community for the maintenance of biodiversity at regional scale in a context of global change. Furthermore, another plausible explanation is the presence of vagrants or tourist species, i.e., rare species which only occasionally appear and do not belong to the community. These vagrants could increase artificially the species richness in temporary wetlands repeatedly sampled. Nonetheless, they may be important elements in the biodiversity of these ecosystems because play a significant role on the ecosystem resilience (Jiménez-Valverde and Hortal, 2003).

\section{CONCLUSIONS}

Hydrology and salinity are crucial factors determining species richness and composition of zooplankton (branchiopods and copepods) in Mediterranean wetlands. We have found that the most vulnerable wetlands, the temporary ones, are unique sites for supporting rare aquatic species not present in permanent wetlands. As Collinson et al. (1995) indicated, the conservation of temporary wetlands should seek to protect all taxa, and micro-crustaceans should be included in future conservative legislation. Moreover, it is important to note that Mediterranean region is considered as a sensitive area to climatic changes (Sánchez-Fernández et al., 2004). Although Mediterranean water bodies are characterized by extreme natural water level fluctuations in response to irregular precipitation patterns (Álvarez-Cobelas et al., 2005), global climatic change is projected to amplify this pattern as a consequence of: i) the increase of temperatures; ii) the elevation of evapotranspiration rates; iii) the diminution of precipitation levels; and iv) the increase of summer droughts (Coops et al., 2003; Angeler, 

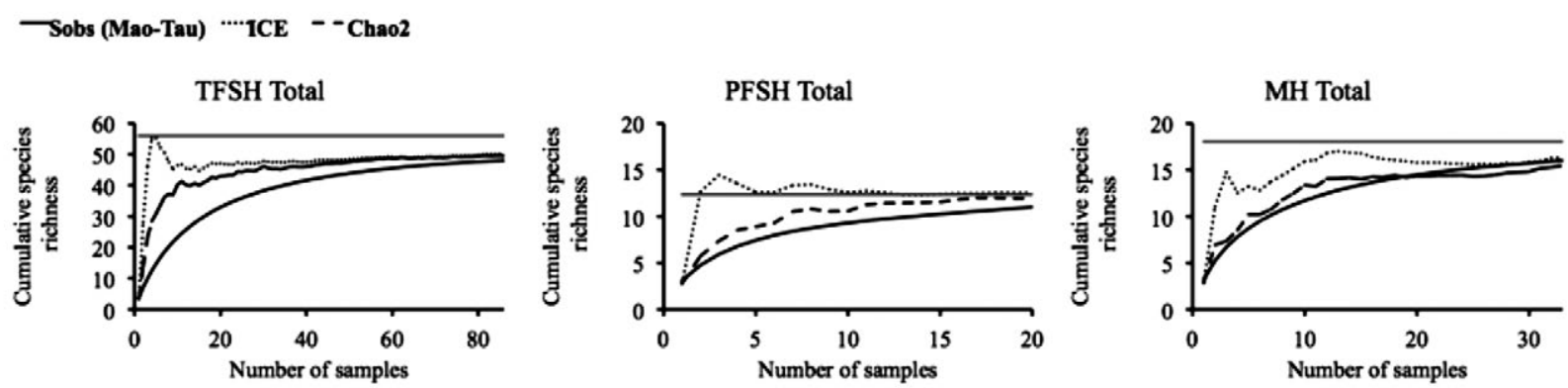

TFSH Branchiopods

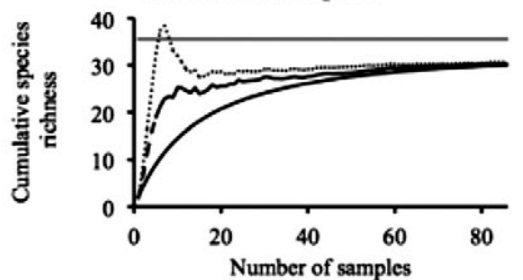

PFSH Branchiopods
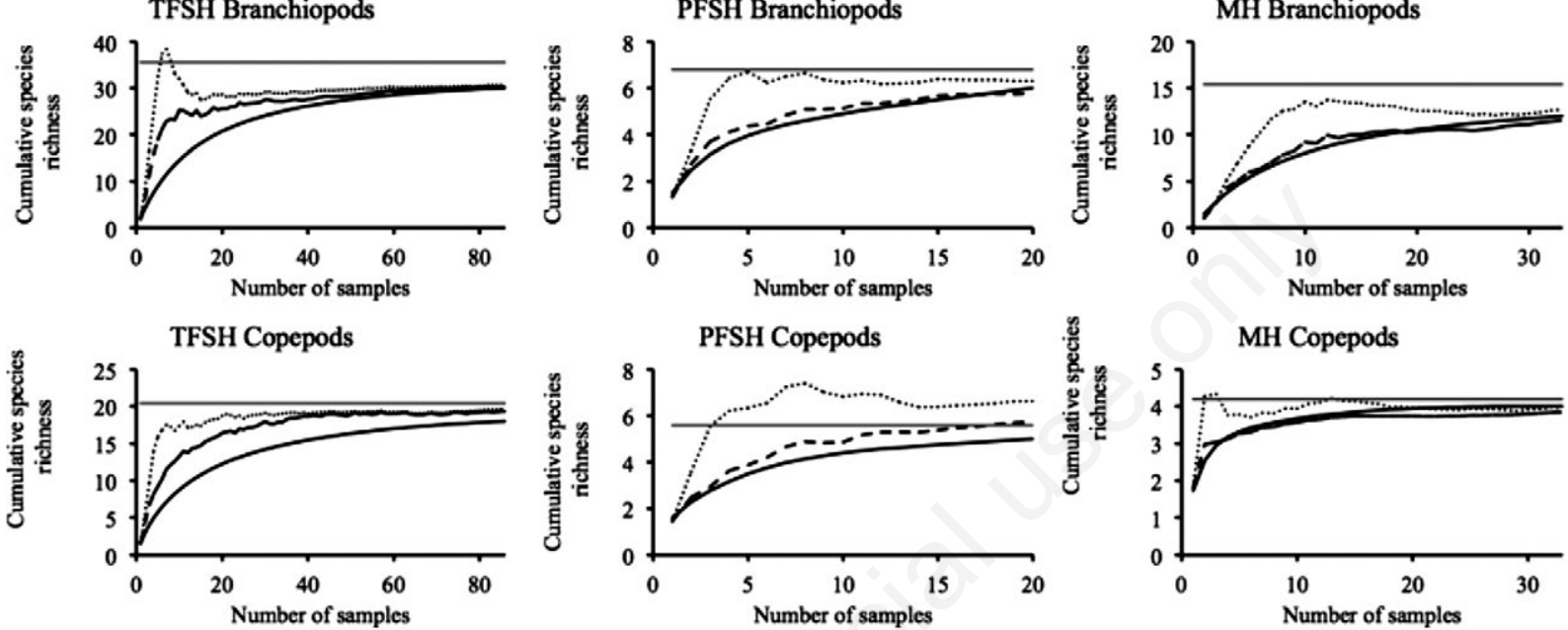

Fig. 3. Zooplankton species richness observed ( $\mathrm{Sobs}$ ) and non-parametric estimators (ICE and Chao2) used to predict the species richness in different wetland types. Each graph shows the total value of species richness (grey solid line), according to Colwell (2005).

2007; García-Jurado et al., 2012). These fluctuations will be most pronounced in closed-basin lakes, where the balance between precipitation and evaporation controls water levels (Marsh and Lesack, 1996). As a direct result of all these processes, changes in hydrology (i.e., flooding period and water permanence) and salinity are expected (Beklioglu et al., 2007). All these changes would affect the species that inhabit them, because their ability to adapt the new environmental conditions is limited, which would increase extinction rates and the loss of biodiversity (Hughes, 2000; McCarty, 2001; Walther et al., 2002; Root et al., 2003). The adequate knowledge about species composition and diversity that support these systems would increase our ability to manage them and to implement efficient conservation strategies that could help mitigating future effects of global climate change (Angeler, 2007). Even more, Mediterranean wetlands are also seriously affected by human impacts (agriculture or urban development) that induce other forms of stress that will make more unpredictable and complex the biological responses to climate change (IPCC, 2007).

\section{ACKNOWLEDGMENTS}

Our thanks go to the Consejería de Medio Ambiente (Junta de Andalucía) for permission to take zooplankton samples in the protected wetlands, and Adrian Green, a native speaker who revised the manuscript. We also thank two anonymous reviewers for their useful comments, which have greatly improved the manuscript.

\section{REFERENCES}

AEMET, 2011. [Atlas climático ibérico].[Book in Spanish]. Ministerio de Medio Ambiente y Medio Rural y Marino: $79 \mathrm{pp}$.

Alfonso G, Belmonte G, 2011. Calanoida (Crustacea Copepoda) from the inland waters of Apulia (south-eastern Italy). J. Limnol. 70:57-68.

Alfonso G, Belmonte G, 2013. Neolovenula alluaudi (Guerne and Richard, 1890) (Calanoida: Diaptomidae: Paradiaptominae): first record in Italy and review of geographical distribution. J. Limnol. 72:251-261.

Allan DG, Seaman MT, Kaletja B, 1995. The endorheic pans of South Africa, p. 75-101. In: G.I. Cowan (ed) Wetlands of 
South Africa. Department of Environmental Affairs and Tourism.

Alonso M, 1996. [Fauna Iberica. Crustacea, Branchiopoda].[Book in Spanish]. Museo Nacional de Ciencias Naturales: 488 pp.

Alonso M, 1998. [Las lagunas de la España Penínsular].[Article in Spanish]. Limnetica 15:1-176.

Álvarez-Cobelas M, Rojo C, Angeler DG, 2005. Mediterranean limnology: current status, gaps and the future. J. Limnol. 64:13-29.

Angeler DG, 2007. Resurrection ecology and global climate change research in freshwater ecosystems. J. N. Am. Benthol. Soc. 26:12-22.

Angeler DG, Viedma O, Sánchez-Carrillo S, 2008. Conservation issues of temporary wetland Branchiopoda (Anostraca, Notostraca: Crustacea) in a semiarid agricultural landscape: what spatial scales are relevant? Biol. Conserv. 141: 1224-1234.

Beja P, Alcazar R, 2003. Conservation of Mediterranean temporary ponds under agricultural intensification: an evaluation using amphibians. Biol. Conserv. 114:317-326.

Beklioglu M, Romo S, Kagalou I, 2007. State of the art in the functioning of shallow Mediterranean lakes: workshop conclusions. Hydrobiologia 584:317-326.

Bianchi F, Acri F, Aubry FB, Berton A, Boldrin A, Carmatti E, Cassin D, Comaschi A, 2003. Can plankton communities be considered as bioindicators of water quality in the Lagoon of Venice? Mar. Pollut. Bull. 46:964-971.

Boix D, Gascón S, Sala J, Badosa A, Brucet S, López-Flores R, Martinoy M, Gifre J, Quintana XD, 2008. Patterns of composition and species richness of crustaceans and aquatic insects along environmental gradients in Mediterranean water bodies. Hydrobiologia 597:53-69.

Boix D, Gascón S, Sala J, Martinoy M, Gifre J, Quintana XD, 2005. A new index of water quality assessment in Mediterranean wetlands based on crustaceans and insects assemblages: the case of Catalunya (NE Iberian Peninsula). Aquat. Conserv. 15:635-651.

Boronat L, Miracle MR, Armengol X, 2001. Cladoceran assemblages in a mineralization gradient. Hydrobiologia 442:75-88.

Brucet S, Boix D, Gascón S, Sala J, Quintana XD, Badosa A, Søndergaard M, Lauridsen TL, Jeppesen E, 2009. Species richness of Crustacean zooplankton and trophic structure of brackish lagoons in contrasting climate zones: north temperate Denmark and Mediterranean Catalonia (Spain). Ecography 32:692-702.

Brucet S, Boix D, López-Flores R, Badosa A, Moreno-Amich R, Quintana XD, 2005. Zooplankton structure and dynamics in permanent and temporary Mediterranean salt marshes: taxon-based and size-based approaches. Arch. Hydrobiol. 162:535-555.

Brucet S, Boix D, López-Flores R, Badosa A, Moreno-Amich R, Quintana XD, 2006. Size and species diversity of zooplankton communities in fluctuating Mediterraean salt marshes. Estuar. Coast. Shelf Sci. 67:424-432.

Capel Molina JJ, 1981. [Los climas de España].[Book in Spanish]. Oikos-Tau: 432 pp.

Caramujo MJ, Boavida MJ, 2000. The crustacean communities of river Tagus reservoirs. Zooplankton structure as reservoir trophic state indicator. Limnetica 18:37-56.
Caramujo MJ, Boavida MJ, 2010. Biological diversity of copepods and cladocerans in Mediterranean temporary ponds under periods of contrasting rainfall. J. Limnol. 69:1-12.

Céréghino R, Ruggiero A, Marty P, Angélibert S, 2008. Biodiversity and distribution patterns of freshwaters invertebrates in farm ponds of a south-western French agricultural landscape. Hydrobiologia 597:43-51.

Collinson NH, Biggs J, Corfield A, Hodson MJ, Walker D, Whitfied M, Williams PJ, 1995. Temporary and permanent ponds: an assessment of the effects of drying out on the conservation value of aquatic macroinverterbrate communities. Biol. Conserv. 74:125-133.

Colwell RK, 2005. EstimateS: Statistical estimation of species richness and shared species from samples. Version 8.0. User's Guide and application published at: http://purl.oclc.org/ estimate.

Connell JH, 1978. Diversity in tropical rainforests and coral reefs. Science 199:1302-1310.

Coops H, Beklioglu M, Crisman TL, 2003. The role of waterlevel fluctuations in shallow lake ecosystems - workshop conclusions. Hydrobiologia 506-509:23-27.

Dantín J, 1929. [Localización de las zonas endorreicas de España].[Article in Spanish]. Mem. Real Soc. Esp. Hist. Nat. 15:829-836.

Dantín J, 1940. [La aridez y el endorreismo en España. El endorreismo bético].[Article in Spanish]. Est. Geogr. 1:75-117.

De Bie T, Declerck S, Martens K, De Meester L, Brendonck L, 2008. A comparative analysis of cladoceran communities from different water body types: patterns in community composition and diversity. Hydrobiologia 597:19-27.

De Meester L, Declerck S, Stoks R, Louette G, Van de Meuter F, De Bie T, Michels E, Brendonck L, 2005. Ponds and pools as model systems in conservation biology, ecology and evolutionary biology. Aquat. Conserv. 15:715-725.

De Stasio BT, 1989. The seed bank of a freshwater crustacean: copepodology for the plant ecologist. Ecology 70:1377-1389.

Denslow JS, 1985. Disturbance-mediated coexistence of species, p. 307-321. In: S.J.A. Pickett and P.S. White (eds.), The ecology of natural disturbance and patch dynamics. Academic Press Inc.

Díaz de la Guardia C, Alba F, Trigo MM, Galán C, Ruiz L, Sabariego S, 2003. Aerobiological analysis of Olea europaea L. pollen in different localities of southern Spain. Grana 42:234-243.

Dussart B, 1967. [Calanoides et Harpacticoides. Les Copépodes des eaux Continentales d'Europe Occidentale. Tome I].[Book in French]. Boubée \& Cie: 500 pp.

Dussart B, 1969. [Cyclopoides et Biologie. Les Copépodes des eaux Continentales d'Europe Occidentale. Tome II].[Book in French]. Boubée \& Cie: 292 pp.

Dussart BH, Defaye D, 1995. Copepoda. Introduction to the Copepoda. Guides to the identification of the microinvertebrates of the continental waters of the world, 7 . SPB Academic Publishers: 277 pp.

Einsle U, 1996. Copepoda: Cyclopoida. Genera Cyclops, Megacyclops, Acanthocyclops. Guides to the identification of the microinvertebrates of the continental waters of the world, 10. SPB Academic Publishers: 83 pp.

Eitam A, Blaustein L, Van Damme K, Dummont HJ, Martens $\mathrm{K}, 2004$. Crustacean species richness in temporary pools: 
relationships with habitat traits. Hydrobiologia 525:125-130.

Esteban GF, Finlay BJ, 2010. Conservation work is incomplete without cryptic biodiversity. Nature 463:293.

Fahd K, Arechederra A, Florencio M, León D, Serrano L, 2009. Copepods and branchiopods of temporary ponds in the Doñana Natural Area (SW Spain): a four-decade record (1964-2007). Hydrobiologia 634:219-230.

Frisch D, Moreno-Ostos E, Green AJ, 2006. Species richness and distribution of copepods and cladocerans and their relation to hydroperiod and other environmental variables in Doñana, south-west Spain. Hydrobiologia 556:327-340.

Galotti A, Finlay BJ, Jiménez-Gómez F, Guerrero F, Esteban GF, 2014. Most ciliated protozoa in extreme environments are cryptic in the 'seed bank'. Aquat. Microb. Ecol. 72:187-193.

Gannon JE, Stemberger RS, 1978. Zooplankton (especially crustaceans and rotifers) as indicators of water quality. Trans. Am. Microscopial Soc. 97:16-35.

García-Jurado F, de Vicente I, Galotti A, Reul A, Jiménez-Gómez F, Guerrero F, 2012. Effect of drought conditions on plankton community and on nutrient availability in a oligotrophic high mountain lake. Arct. Antarct. Alp. Res. 44:50-61.

García-Muñoz E, Gilbert JD, Parra G, Guerrero F, 2010. Wetlands classification for amphibian conservation in Mediterranean landscapes. Biodivers. Conserv. 19:901-911.

Gascón S, Boix D, Sala J, 2009. Are different biodiversity metrics related to the same factors? A case study from Mediterranean wetlands. Biol. Conserv. 142:2602-2612.

Gilbert JD, de Vicente I, Jiménez-Melero R, Parra G, Guerrero F, 2014. Selecting priority conservation areas based on zooplankton diversity: the case of Mediterranean wetlands. Mar. Freshwater Res. 65:857-871.

González-Oreja JA, De la Fuente-Díaz-Ordaz AA, HernándezSantín L, Buzo-Franco D, Bonache-Regidor C, 2010. [Evaluación de estimadores no paramétricos de la riqueza de especies. Un ejemplo con aves en áreas verdes de la ciudad de Puebla, México].[Article in Spanish]. Anim. Biodivers. Conserv. 33:31-45.

Guerrero F, 2009. [Humedales continentales andaluces], p. 357400. In: F.X. Niell (ed.), [Proyecto Andalucía Naturaleza. Ecología V, 1].[Book in Spanish]. Publicaciones Comunitarias.

Guerrero F, Parra G, Jiménez-Gómez F, Salazar C, JiménezMelero R, Galotti A, García-Muñoz E, Lendínez ML, Ortega F, 2006. Ecological studies in Alto Guadalquivir wetlands: a first step towards the application of conservation plans. Limnetica 25:95-106.

Hortal J, Lobo JM, 2002. [Una metodología para predecir la distribución especial de la diversidad biológica].[Article in Spanish]. Ecología 16:151-178.

Hortal J, Paulo A, Borges V, Gaspar C, 2006. Evaluating the performance of species richness estimators: sensitivity to sample grain size. J. Anim. Ecol. 75:274-287.

Hughes L, 2000. Biological consequences of global warming: is the signal already apparent? Trends Ecol. Evol. 15:56-61.

IPCC, 2001. Climatic change 2007: synthesis report. IPCC: $104 \mathrm{pp}$.

Jeppesen E, Nõges P, Davidson TA, Haberman J, Nõges T, Blank K, Lauridsen TL, Søndergaard M, Sayer C, Laugaste R, Johansson LS, Bjerring R, Amsinck SL, 2011. Zooplankton as indicators in lakes: a scientific-based plea for including zooplankton in the ecological quality assessment of lakes according to the European Water Framework Directive (WFD). Hydrobiologia 676:279-297.

Jiménez-Valverde A, Hortal J, 2003. [Las curvas de acumulación de especies y la necesidad de evaluar la calidad de los inventarios biológicos].[Article in Spanish]. Rev. Iber. Aracnol. 8:151-161.

Longino JT, Coddington J, Colwell RK, 2002. The ant fauna of a tropical rain forest: estimating species richness three different ways. Ecology 83:689-702.

Marrone F, Barone R, Flores LN, 2006. Ecological characterization and cladocerans, calanoid copepods and large branchiopods of temporary ponds in a Mediterranean island (Sicily, southern Italy). Chem. Ecol. 22 (Suppl.1):181-190.

Marsh P, Lesack LFW, 1996. The hydrologic regime of perched lakes in the Mackenzie Delta: potential responses to climate change. Limnol. Oceanogr. 41:849-856.

McCarty JP, 2001. Ecological consequences of recent climate change. Conserv. Biol. 15:320-331.

Miracle MR, 1982. Biogeography of the freshwater zooplanktonic communities of Spain. J. Biogeogr. 9:455-467.

Moreno CE, Halffter G, 2000. Assessing the completeness of bat biodiversity inventories using species accumulation curves. J. Appl. Ecol. 37:149-158.

Myers N, Mittermeier RA, Mittermeier CG, da Fonseca GAB, Kent J, 2000. Biodiversity hotspots for conservation priorities. Nature 403:853-858.

Oertli B, Biggs J, Céréghino R, Grillas P, Jolu P, Lachavanne JB, 2005. Conservation and monitoring of pond biodiversity: introduction. Aquat. Conserv. 15:535-540.

Ortega F, Parra G, Guerrero F, 2003. [Los humedales del Alto Guadalquivir: inventario, tipologías y estado de conservación], p. 113-123. In: M Paracuellos (ed), [Ecología, manejo y conservación de los humedales].[Book in Spanish]. Instituto de Estudios Almerienses.

Ortega F, Parra G, Guerrero F, 2006. [Usos del suelo en las cuencas hidrográficas de los humedales del Alto Guadalquivir: importancia de una adecuada gestión].[Article in Spanish]. Limnetica 25:723-732.

Parra G, Matias NG, Guerrero F, Boavida MJ, 2009. Short term fluctuations of zooplankton abundance during autumn circulation in two reservoirs with contrasting trophic state. Limnetica 28:175-184.

Por FD, 1980. A classification of hypersaline waters, based on trophic criteria. Mar. Ecol. 1:121-131.

Ranga-Reddy Y, 1994. Copepoda: Calanoida: Diaptomidae. SPB Academic Publishers: $221 \mathrm{pp}$.

Ripley BJ, Simovich MA, 2009. Species richness on islands in time: variation in ephemeral pond crustacean communities in relation to habitat duration and size. Hydrobiologia 617:181-196.

Root TL, Price JT, Hall KR, Schneider SH, Rosenzweig C, Pounds JA, 2003. Fingerprints of global warming on wild animals and plants. Nature 421:57-60.

Sánchez-Fernández D, Abellán P, Velasco J, Millán A, 2004. Selecting areas to protect the biodiversity of aquatic ecosystems in a semiarid Mediterranean region. Aquat. Conserv. 14:465-479.

Sarma SSS, Nandini S, Morales-Ventura J, Delgado-Martínez I, González-Valverde L, 2006. Effects of $\mathrm{NaCl}$ salinity on the population dynamics of freshwater zooplankton (rotifers and cladocerans). Aquat. Ecol. 40:349-360. 
Semlitsch R, Bodie J, 2005. Are small, isolated wetlands expendable? Conserv. Biol. 12:1129-1133.

Shurin JB, Arnott SE, Hillebrand H, Longmuir A, Pinel-Alloul B, Winder M, Yan ND, 2007. Diversity-stability relationship varies with latitude in zooplankton. Ecol. Lett. 10:127-134.

Soberon J, Llorente L, 1993. The use of species accumulation functions for the prediction of species richness. Conserv. Biol. 7:480-488.

StatSoft Inc, 2004. STATISTICA (data analysis software system), ver. 7. Available from: http//www.statsoft.com

Vandekerkhove J, Declerck S, Jeppesen E, Conde-Porcuna JM, Brendonck L, De Meester L, 2005. Dormant propagule banks integrate spatio-temporal heterogeneity in cladoceran communities. Oecologia 142:109-116.
Vera JA, 1994. [Geología de Andalucía].[Article in Spanish]. Rev. Asoc. Esp. Enseñ. Cienc. Tierra 2:306-315.

Walther BA, Martin JL, 2001. Species richness estimation of bird communities: how to control for sampling effort? Ibis 143:413-419.

Walther BA, Moore JL, 2005. The concepts of bias, precision and accuracy, and their use in testing the performance of species richness estimators, with a literature review of estimator performance. Ecography 28:815-829.

Walther GR, Post E, Convey P, Menzel A, Parmesan C, Beebee TJC, Fromentin JM, Hoegh-Gulberg O, Bairlein F, 2002. Ecological responses to recent climate change. Nature 416:389-395.

Williams WD, 1999. Conservation of wetlands in drylands: a key global issue. Aquat. Conserv. 9:517-522. 